УДК. 598.2(282.247.118.044)

doi: $10.31140 /$ j.vestnikib.2020.2(213).2

\title{
ПТИЦЫ РАЙОНА ОЗЕРА УРДЮЖСКОЕ И НИЖНЕГО ТЕЧЕНИЯ РЕКИ СУЛЫ (МАЛОЗЕМЕЛЬСКАЯ ТУНДРА)
}

\author{
О.Ю. Минеев, Ю.Н. Минеев, С.К. Кочанов \\ Институт биологии Коми научного центра Уральского отделения Российской академии наук, Сыктывкар \\ E-mail: mineev@ib.komisc.ru; kochanov@ib.komisc.ru
}

\begin{abstract}
Аннотация. В статье проанализированы результаты изучения распространения и численности птиц в районе оз. Урдюжское и низовьях р. Сула в 1979, 1982, 1986 и 2018 гг. В ходе исследований зарегистрировано 98 видов птиц, принадлежащих к восьми отрядам: гагарообразные (2 вида), пластинчатоклювые (19), соколообразные (13), курообразные (4), журавлеобразные (1), ржанкообразные (27), дятлообразные (2), воробьинообразные (30). Из общего числа выявленных видов гнездятся 64, предположительно гнездятся 10, встречено на миграциях шесть, залетными являются пять, характер пребывания не выяснен для 14 видов птиц. В составе населения птиц района оз. Урдюжское за более чем 30-летний период (с 1986 по 2018 г.) выявлены заметные изменения. Вероятно, они связаны как с межгодовой динамикой видового разнообразия и численности, так с изменением фактора беспокойства в связи с прекращением промыслового лова рыбы в летний период, в результате чего значительно снизилась численность серых ворон, район стал местом крупной концентрации лебедей-кликунов на линьке, увеличилась плотность гнездования орланов-белохвостов. Исследования, проведенные в районе оз. Урдюжское, показали, что эта территория является важным местом обитания и линьки кликуна, ржанкообразных птиц, орлана-белохвоста и соответствует критериям водно-болотных угодий, принятых Рамсарской конвенцией.
\end{abstract}

Ключевые слова: Малоземельская тундра, оз. Урдюжское, бассейн нижней Сулы, распространение и численность птиц

\section{Введение}

Впервые работы по изучению фауны, распространения, численности и миграций птиц в районе оз. Урдюжское были проведены сотрудниками Института биологии Коми филиала академии наук ССCP в 1979, 1982 и 1986 гг. Результаты исследований не нашли своего отражения в отдельной статье, но материалы были частично опубликованы в ряде монографий (Минеев, 2003, 2005, 2009). Использованы данные, полученные Б.Т. Семеновым (1939), в месте, ближайшем к району исследований (бассейн р. Сулы). В целях выявления изменений в составе орнитофауны, произошедших за 32-летний период, было проведено обследование территории в летний период в 2018 г. Настоящая работа посвящена анализу результатов работ, проведенных в предыдущие годы, и сравнению их с новыми данными, полученными в ходе исследований в 2018 г. В статье также приводятся сведения об орнитофауне Урдюжской Виски, низовьев рек Сойма и Сула.

Озеро Урдюжское расположено в юго-восточной части Малоземельской тундры ( $67^{\circ} 14^{\prime}$ с.ш., $50^{\circ} 19^{\prime}$ в.д.) на территории Ненецкого автономного округа на высоте 31 м над ур.м. Основной тип ландшафта - озерно-лесотундровый. Бугристые и травяно-моховые болота здесь чередуются с редколесьями из ели, березы и зарослями кустарников (Дедов, 2006). Имеется большое количество проточных и бессточных озер различного происхождения. Почвы глее-подзолистые и болотнотундровые, местами имеются песчаные выдувы. Максимальные высоты в районе водоема варьируют от 53 до 59 м над ур.м. (Горбацкий, 1967). Площадь озера составляет 61.7 км², в него впа- дают небольшие речки и ручьи, площадь водосбора - 306 км $^{2}$. Минимальная глубина водоема составляет 1 м, максимальная - 15 м. Преобладают минимальные глубины. Из озера вытекает сильно меандрирующая быстроводная р. Урдюжская Виска (длина около 80 км), впадающая в p. Сойма, которая в свою очередь соединена с p. Сула (левый приток р. Печора).

Берега оз. Урдюжское низкие, болотистые и высокие, местами обрывистые. Они частично безлесные, местами покрыты лесными массивами или ивняками. Прибрежные участки водоема большей частью мелководные и зарастают водной растительностью.

В прилежащих районах оз. Урдюжское проводится зимний выпас и прогон стад домашних оленей к летним пастбищам. Расстояние от г. Нарьян-Мар до оз. Урдюжское составляет 150 км, от населенного пункта с. Коткино - 50 км.

В прежние годы водоем использовался как рыбохозяйственный участок (колхоз с. Коткино), здесь осуществляли промысловый лов рыбы.

\section{Материал и методы}

В сентябре-октябре 1979 г. обследованы акватория оз. Урдюжское, окружающая тундра, бассейн р. Урдюжская Виска, низовья рек Сула и Сойма. Работы продолжены в июне-июле, сентябре-октябре 1982 г., июне-августе 1986 г. и с 20 июня по 9 июля 2018 г.

Изучение видового состава, биотопического распределения и численности птиц, краткое геоботаническое и ландшафтное описание территории, водотоков и типов озер выполнено во время пешеходных и лодочных маршрутов. Ширина 
учетной полосы на пешеходных маршрутах была дифференцирована: белую куропатку, водоплавающих, хищных, чайкообразных и врановых птиц учитывали в полосе 500 м; средних и крупных куликов, полярную крачку - 300 м; мелких куликов и воробьиных - 100 м. Протяженность пешеходных маршрутов составила 20 км. Лодочные маршруты (250 км) осуществлены по оз. Урдюжское, в низовьях рек Сойма, Сула и по р. Урдюжская Виска. Список видов приведен согласно таксономической сводке Л.С. Степаняна (2003).

\section{Результаты}

Краснозобая гагара Gavia stellata (Pontoppidan, 1763). Гнездящийся вид. В летний период 2018 г. плотность населения краснозобой гагары по данным пешеходных маршрутов в среднем составила 0.2 особи $/$ м $^{2}$. Одинотные, пары и группы птиц (до трех особей) встречены преимущественно на термокарстовых озерах в мохово-лишайниково-кустарничковой тундре.

Высокая плотность населения гагар (0.5 пары) $\kappa^{2}$ ) отмечена в районе оз. Урдюжское в летний период 1986 г. Нелетного птенца наблюдали 27 сентября 1982 г. Первые отлетающие на север гагары (грушшы но 4-5 особей) зарегистрированы 27 июля 1986 г. (Минеев, 2009).

Чернозобая гагара Gavia arctica (Linnaeus, 1758). Гнездящийся вид. Плотность населения чернозобой гагары в летний период 1986 г. в среднем была равна 1.2 особи/км². Миграция чернозобых гагар на северо-северо-восток зарегистрирована с 10 по 22 сентября (1979, 1982 гг.) (Минеев, 2009).

В летний период 2018 г. одиночных птиц и пары гагар встречали на озерах, заливах и расширениях рек. Плотность населения чернозобой гагары в тундровых местообитаниях района оз. Урдюжское в среднем составила 0.2 особи $/ \mathrm{\kappa м}^{2}$. В низовьях р. Сула и на других водотоках численность птиц была равна 0.1 особи на 10 км учетного маршрута. В конце первой декады июля 2018 г. в вечернее время (21-22 ч) отмечены групповые «концерты» чернозобых гагар на озерах.

Черная казарка Branta bernicla (Linnaeus, 1758). В районе оз. Урдюжское черных казарок, мигрирующих в юго-западном и западном направлениях, наблюдали 25 сентября 1979 г. (Минеев, 2009).

Белолобый гусь Anser albifrons (Scopoli, 1769). C морского побережья, где гуси концентрируются перед отлетом, часть птиц летит в западном и юго-западном направлениях через район оз. Урдюжское. В этом районе первые стаи мигрантов зарегистрированы 12-25 сентября 1982 г., последние - 2 октября 1979 г. (Минеев, 2009).

Гуменник Anser fabalis (Latham, 1787). Гнездящийся вид. Массовые скопления линных гуменников ранее были обычны на оз. Урдюжское и реках Большой и Средний Гусинец (Минеев,
2003, 2009). Плотность населения птиц в летний период 1986 г. не превышала 2.0 особи $/$ м $^{2}$, численность на водотоках -4.5 особи на 10 км учетного маршрута.

В период исследований 2018 г. гуменник был редок. На р. Урдюжская Виска численность гусей составила 0.6 особи на 10 км лодочного маршрута. В верхнем течении р. Урдюжская Виска 7 июля 2018 г. встречено два выводка гуменника (два и четыре птенца в возрасте 3-4 дня). Выводки держались раздельно. В конце июня в утренние и вечерние часы происходили незначительные перемещения гуменников (пары и стайки до пяти особей) на высоте 20 м в северо-северо-западном и северо-восточном направлениях.

Лебедь-кликун Cygnus cygnus (Linnaeus, 1758). Гнездящийся вид. В районе оз. Урдюжское высокая плотность гнездования лебедя-кликуна (1.7 особи $/ \mathrm{kм}^{2}$ ) отмечена в 1986 г. В особо благоприятных местобитаниях (озерные мелководья с богатой водной растительностью, пойменные местообитания) гнездились несколько пар. На акватории оз. Урдюжское гнезда кликунов (7 пар) были размещены на прибрежных мелководьях среди водной растительности и сплавинных травяных ос'тровках на расс'тоянии 1.5-6.0 км друг от друга.

Первая волна миграции лебедей-кликунов поодиночке, парами и стаями (по 16-18 особей) зарегистрирована 7-21 сентября 1979 г. Во второй миграционной волне (21-28 сентября) появились птицы с выводками. В начале октября пролетные стаи (по 30-100 особей) были без выводков. В заключительной стадии миграции (середина-начало третьей декады октября) летели пары, стаи и птицы с выводками. Пролет кликунов в 1982 г. окончился с появлением льда на водоемах - 14 октября (Минеев, 2009, 2014).

В 2018 г. кликун был многочисленным $(2.6$ особи $/ \mathrm{KM}^{2}$ ) в тундровых и лесотундровых местообитаниях, но гнездование не зарегистрировано. На р. Урдюжская Виска численность лебедей была равна 0.3 особи на 10 км учетного маршрута. Кликуны (стаи от 6 до 134 птиц) регулярно концентрировались в прибрежных мелководных частях озера с обилием рдестов. Общая численность птиц в районе оз. Урдюжское варьировала от 300 до 350 особей. Первые линяющие кликуны зарегистрированы 23 июня 2018 г., массовая линька птиц происходила с конца третьей декады июня. В это же время кликуны (стайки по 3-11 особей) перемещались на высоте 15-35 м вдоль берегов оз. Урдюжское в северо-восточном и северо-западном направлениях.

Кряква Anas platyrhynchos Linnaeus, 1758. Гнездящийся вид. Кряква встречена в летний период 2018 г. на р. Урдюжская Виска, где ее численность составила 0.6 особи на 10 км учетного маршрута. Там же 7 июля 2018 г. отмечены выводки кряквы, в которых было 5-7, в среднем 
$(\mathrm{n}=3) 6.3$ птенца. Возраст утят в выводках варьировал от 3 до 7 дней. На разнотравных лугах низовий р. Сула численность кряквы была равна 3.3 особи $/ \mathrm{KM}^{2}$.

Чирок-свистунок Anas crecca Linnaeus, 1758. Гнездящийся вид. На тундровых водоемах в районе оз. Урдюжское с 22 июня по 31 июля 1986 г. отмечены небольшие стаи (до 30 особей) селезней. Плотность населения уток была равна 0.9 особи $/ \mathrm{\kappa м}^{2}$. Кладки в стадии насиживания найдены 13 июня (9 яиц) и 5 июля (6 яиц) 1986 г. Выводки по достижении утятами массы в 150200 г оставались нелетными на 10-14 сентября 1979 г. В это время у части молодых птиц пеньки отрастающего покровного оперенья располагались на груди, животе, бедрах, маховые были еще в трубке, у других они отрасли наполовину (Минеев, 2009).

В 2018 г. встречены одиночные, пары и стайки (3-10 особей) чирков-свистунков. На р. Урдюжская Виска 7 июля 2018 г. учтено 16 выводков свистунка, в которых было 3-11, в среднем (n=12) 5.7 утенка в возрасте 2-4 дней. Численность уток в этих местообитаниях была равна 5.0 особи на 10 км лодочных маршрутов.

Свиязь Anas penelope Linnaeus, 1758. Гнездящийся вид. В летний период 1986 г. встречены одиночные и пары свиязей. В районе оз. Урдюжское откладка яиц свиязью происходила с 15 по 29 июня 1986 г. (Минеев, 2005, 2009). На р. Урдюжская Виска численность уток в 2018 г. была равна 0.6 особи на 10 км лодочного маршрута. Здесь же 7 июля 2018 г. отмечено два выводка свиязи. В низовьях р. Сула на разнотравных лугах численность свиязи составила 5.6 особи $/$ м $^{2}$.

Шилохвость Anas acuta Linnaeus, 1758. Гнездящийся вид. В летний период 1986 г. в тундровых местообитаниях плотность населения шилохвости была равна 0.5 особи $/ \mathrm{\kappa м}^{2}$. Небольшой пролет (стаи до 30 особей) на юг происходил с 23 сентября 1979 г. (Минеев, 2009).

В 2018 г. встречали одиночных птиц, а выводок с девятью утятами встречен в районе истока Урдюжской виски 6 июля. В тундровых местообитаниях плотность населения уток была равна 0.2 особи $/ \kappa м^{2}$. На р. Урдюжская Виска численность шилохвости составила 0.6 особи на 10 км лодочного маршрута.

Чирок-трескунок Anas querquedula Linnaeus, 1758. В районе оз. Урдюжское 16 июля 1986 г. добыта самка трескунка с наседным пятном, 29 июля - линная самка (Минеев, 2009).

Широконоска Anas clypeata Linnaeus, 1758. В 1986 г. широконоска зарегистрирована на гнездовании, а в летний период 2018 г. не отмечена в районе оз. Урдюжское. В 2018 г. птиц наблюдали на разнотравных лугах низовий р. Сула, где их численность была равна 6.7 особи/км². Осенью 1979 г. последних мигрирующих уток в районе оз. Урдюжское наблюдали 30 сентября (Минеев, 2009).
Хохлатая чернеть Aythya fuligula (Linnaeus, 1758). Гнездящийся вид. В 1986 г. численность хохлатой чернети в среднем была равна 2.5 особи/ $\mathrm{kм}^{2}$, на водотоках - 10.9 особи на 10 км учетного маршрута. В яйцеводе самки, добытой из пары 28 июня 1986 г., обнаружено яйцо без скорлупы. Судя по разорванным фолликулам, до этого она уже снесла три яйца. На озерах зарегистрированы скопления линяющих уток (Минеев, 2009).

В летний период 2018 г. отмечены пары и стайки (по 5-10 особей) хохлатых чернетей. Плотность населения чернетей в тундровых местообитаниях в районе оз. Урдюжское составила 1.1 особи $/$ м $^{2}$. Численность уток на р. Урдюжская Виска была равна 0.1 особи на 10 км учетного маршрута. В выводке, отмеченном здесь 7 июля 2018 г., было три птенца.

Морская чернеть Aythya marila (Linnaeus, 1761). Возможно, гнездится. Пары морских чернетей наблюдали на озерах в мохово-лишайниковой тундре. Численность уток в этих местообитаниях в период исследований 2018 г. была равна 0.2 особи $/$ м $^{2}$. Стайки (до 50 особей) чернетей зарегистрированы на акватории оз. Урдюжское. Плотность населения у'ток в ле'тний период 1986 г. была равна 0.6 особи/км².

Морянка Clangula hyemalis (Linnaeus, 1758). Гнездящийся вид. В 1986 г. морянка была многочисленна (плотность населения 1.5 особи/ $\mathrm{\kappa M}^{2}$ ) на гнездовании в районе оз. Урдюжское (Минеев, 2005, 2009). В 2018 г. численность морянки в тундровых местообитаниях была равна 1.3 особи/км². На водоемах зарегистрированы пары и группы морянок, преимущественно самок (до шести особей). В отличие от общего снижения численности вида на территории Ненецкого автономного округа, особенно заметного в приморском регионе (Минеев, 2015), в районе оз. Урдюжское плотность населения морянки изменилась незначительно. Причины этого явления не установлены.

Обыкновенный гоголь Bucephala clangula (Linnaeus, 1758). Гнездящийся вид. В районе оз. Урдюжское слабую миграцию гоголей на юго-запад наблюдали 20-29 сентября 1979 г. В начале сентября 1979 г. добыты молодые птицы. В 2018 г. гоголи не отмечены.

Синьга Melanitta nigra (Linnaeus, 1758). Гнездящийся вид. Плотность населения синьги в районе оз. Урдюжское в летний период 1986 г. была относительно высокой (0.9 особи/км $\left.{ }^{2}\right)$. Численность на водотоках была равна 3.5 особи на 10 км учетного маршрута. Полные кладки найдены 1 и 8 июля 1986 г. (Минеев, 2009). Летом 2018 г. стайки синьги (до восьми особей) встречали на акватории оз. Урдюжское и близлежащих озер.

Обыкновенный турпан Melanitta fusca (Linnaeus, 1758). В 1986 г. численность турпана в районе оз. Урдюжское была равна 0.6 особи $/ \mathrm{kм}^{2}$ (Минеев, 2009). В 2018 г. утки не отмечены. 
Луток Mergus albellus Linnaeus, 1758. Гнездящийся вид. По материалам исследований 1979 , 1982, 1986 гг., луток гнездится по рекам Сула и Сойма, в районе оз. Урдюжское. На оз. Урдюжское и р. Урдюжская Виска молодых птиц наблюдали до 14 октября 1982 г. В районе оз. Урдюжское плотность населения лутка в 1982 г. была относительно высокая -0.4 особи $/$ км² $^{2}$ Молодых птиц наблюдали до конца августа 1979 г. и в первой декаде октября 1982 г. (Минеев, 2009). В 2018 г. утки по 1-2 особи (в основном самцы) встречались на озерах мохово-лишайниковой тундры, часто вместе с морянками, хохлатыми чернетями и средними крохалями. Плотность населения лутка в среднем была равна 0.6 особи $/ \mathrm{kм}^{2}$.

Длинноносый крохаль Mergus serrator Linnaeus, 1758. В районе оз. Урдюжское в периоды предыдущих исследований (1979, 1982, 1986 гг.) средний крохаль был обычен. Плотность населения средних крохалей в среднем была равна 0.2 особи $/$ м $^{2}$ (Минеев, 2009). В 2018 г. - немногочисленный вид. Стайки средних крохалей (12 самцов и семь самок) отмечены 2 июля 2018 г. на оз. Судорма. В стае также держался самец лутка.

Большой крохаль Mergus merganser Linnaeus, 1758. По материалам предыдущих исследований (1979, 1982, 1986 гг.) большой крохаль отмечен в бассейнах рек Сула, Сойма и районе оз. Урдюжское (Минеев, 2009). В летний период 2018 г. уток не наблюдали.

Скопа Pandion haliaetus (Linnaeus, 1758). Гнездование скопы зарегистрировано 9 июня 2018 г. в низовьях р. Сула (устье Харьяского Шара).

Обыкновенный осоед Pernis apivorus (Linnaeus, 1758). Осоед отмечен 21-22 сентября 1979 г. в районе оз. Урдюжское (Минеев, 1980, 2009). Трех одиночных птиц и группу из трех особей, летящих в юго-юго-западном направлении, наблюдали 21 сентября, две одиночные особи и пара осоедов 22 сентября мигрировали в юго-юго-западном направлении.

Черный коршун Milvus migrans (Boddaert, 1783). Черный коршун отмечен 8 июля 2018 г. в районе с. Коткино.

Тетеревятник Accipiter gentilis (Linnaeus, 1758). В районе оз. Урдюжское 19 сентября 1979 г. наблюдали двух особей тетеревятника, мигрирующих на запад, 30 сентября 1982 г. - одну птицу, летящую на запад (Минеев, 2009). В 2018 г. одна особь отмечена на р. Урдюжская виска 21 июня.

Перепелятник Accipiter nisus (Linnaeus, 1758). Перепелятник отмечен 26 июня 2018 г. в березовом лесу на берегу р. Урдюжская Виска.

Зимняк Buteo lagopus (Pontoppidan, 1763). Одинотный зимняк отметен 25 июня 2018 г. в районе оз. Урдюжское около изб бывшего рыбопромыслового участка.
Обыкновенный канюк Buteo buteo (Linnaeus, 1758). Одиночных особей наблюдали 17-22 сентября 1979 г. и 27 июля 1986 г. около ручья и в районе оз. Урдюжское у домов (Минеев, 2009).

Беркут Aquila chrysaetos (Linnaeus, 1758). Возможно, гнездящийся вид. Летом 1986 г. и осенью 1982 г. регулярно регистрировали одиночных птиц, пары и группы (по три особи) беркутов (Минеев, 2009).

Орлан-белохвост Haliaeetus albicilla (Linnaeus, 1758). Гнездящийся вид. В 1986 г. гнездо орлана было сооружено на березе, растущей на берегу p. Средний Гусинец, впадающей в оз. Урдюжское. Гнездо было размещено в развилке сучьев в 9 м от земли и построено из веток березы, ели, багульника и березы карликовой. Лоток выстлан мхом и сухой осокой. Диаметр основания гнезда 157 см, высота гнезда - 67 см, диаметр лотка 67 см и глубина лотка - 15 см. В нескольких метрах находилось старое гнездо. Плотность населения птиц была равна 0.1 особи $/$ км$^{2}$ (Минеев, 2009).

В период исследований 2018 г. одиночные птицы, пары и семейные группы (два родителя и три молодых орлана-белохвоста) встречались главным образом вдоль рек (Сула, Сойма и другие реки, впадающие в оз. Урдюжское), а также в облесенных заливах оз. Урдюжское. В общей сложности здесь отмечено пребывание не менее 6-7 особей. Плотность населения орлана-белохвоста была равна 1.4 особи $/ \mathrm{KM}^{2}$, из них $25 \%$ составили неполовозрелые особи. На р. Урдюжская Виска численность орлана была равна 0.9 , на р. Суле - 0.3 особи на 10 км учетного маршрута.

5 июля 2018 г. в северной части озера на полуострове в 300 м от берега найдено гнездо орлана. Оно было размещено в елово-березовом лесу на березе (высотой 25 м) в развилке ветвей на высоте 10 м. Гнездо диаметром 150 и высотой 60 см было сооружено из ветвей березы. В гнезде находился полностью оперенный птенец. Под гнездом находились останки окуня, плотвы и хохлатой чернети. Другое гнездо найдено в еловоберезовом лесу в 7 м от берега р. Урдюжская Виска. Оно было размещено в развилке ветвей березы (высотой 30 м) на высоте 12 м. Гнездо диаметром и высотой 1 м было построено из ветвей березы. Под гнездом находились кости щуки и гуменника. Пара с гнездовым поведением зарегистрирована на р. Средний Гусинец, впадающей в оз. Урдюжское, но гнездо не было найдено.

В районе оз. Урдюжское орланы, мигрирующие в юго-западном и западном направлениях, отмечены 21 сентября 1979 г. Хорошо выраженный пролет птиц в западном направлении происходил с 21 сентября по 6 октября. В местах размножения орланов регистрировали до середины октября (Минеев, 2009). 
Кречет Falco rusticolus Linnaeus, 1758. Гнездящийся вид. В районе оз. Урдюжское молодых летных кречетов наблюдали в августе 1979 г., одну птицу около домов 29 сентября 1982 г. На берегу р. Средний Гусинец 16 июня 1986 г. найдено гнездо (диаметром 70 и высотой 90 см) кречета. Оно было сооружено в развилке трех сучьев березы (диаметром $28 \mathrm{cm)} \mathrm{на} \mathrm{высоте} 5.5$ м от земли. В гнезде находилось четыре птенца в пуховом наряде с пеньками маховых перьев. При осмотре гнезда 11 июля старший птенец был полностью оперен, остальные были размером с взрослых птиц, в их оперении еще присутствовали пуховые перья. 12 июля птенцы полностью имели первый перьевой наряд, а 14 июля один из них покинул гнездо и находился рядом с ним (на сучке березы). На 20 июля в гнезде оставался один птенец, который покинул гнездо 23 июля (Минеев, 2009).

В 2018 г. кречет был редок, гнездование не зарегистрировано. Одиночные взрослые птицы отмечены 4, 5 и 7 июля на р. Урдюжская Виска и в районах с лесными массивами в северной части оз. Урдюжское.

Сапсан Falco peregrinus Tunstall, 1771. Heбольшой проле' одиночных особей сансана происходил в районе оз. Урдюжское до 25 сентября 1979 г. (Минеев, 2009).

Чеглок Falco subbuteo Linnaeus, 1758. Одиночную особь чеглока наблюдали 16-20 сентября 1979 г. на берегу оз. Урдюжское. Чеглок охотился в зарослях ивы и березы на стрекоз, других крупных насекомых, пуночек, подорожников и прочих воробьиных птиц (Минеев, 2009).

Дербник Falco columbarius Linnaeus, 1758. Гнездящийся вид. В березовом колке на берегу оз. Судорма 1 июля 2018 г. найдено гнездо дербника. Оно располагалось в 6 м от берега в развилке ветвей березы (высотой 12 м) на высоте 5 м. Гнездо высотой 60 и диаметром 70 см было сделано из сучьев березы. Пространство под гнездом было обильно полито пометом. Самка отлетела при появлении людей.

В 1986 г. плотность населения дербника в районе оз. Урдюжское была равна 0.4 особи $/ \mathrm{kм}^{2}$. Гнездование было отмечено на р. Средний Гусинец. Летом 2018 г. дербник был немногочислен. Летящие в южном и юго-западном направлениях дербники отмечены в районе оз. Урдюжское с 14 по 25 сентября 1979 г. (Минеев, 2009).

Белая куропатка Lagopus lagopus (Linnaeus, 1758). Гнездящийся вид. В районе оз. Урдюжское плотность населения куропатки в 1986 г. была равна 2.7 особи $/ \mathrm{Kм}^{2}$, а гнездовая плотность 6.8 пары $/$ м $^{2}$. Первые яйца отложены птицами 31 мая. Однодневные пуховички отмечены с 1 по 5 июля 1986 г. (Минеев, 2009). В 2018 г. белая куропатка была немногочисленна -0.2 особи $/$ км$^{2}$.

Тетерев Lyrurus tetrix (Linnaeus, 1758). Гнездится в лесах по берегам рек Сойма, Сула и в нижнем течении р. Щучья (Семенов, 1939). Начало токования отмечено в средних числах мая, разгар токов - в конце мая. В бассейне р. Сула 24 мая птицы токовали главным образом на деревьях и, в небольшом количестве, по вершинам вытаявших из-под снега холмов. На 1 га учтено по 10-15 токовавших птиц (Семенов, 1939).

Глухарь Tetrao urogallus Linnaeus, 1758. В бассейне р. Щучья токующий глухарь добыт 15 мая в еловом островке на берегу реки. Разгар тока отмечен 24 мая на левом берегу р. Сула, в нем участвовало 17-18 глухарей (Семенов, 1939).

Рябчик Tetrastes bonasia (Linnaeus, 1758). Рябчик гнездится в островных лесах р. Сула (Cеменов, 1939).

Серый журавль Grus grus (Linnaeus, 1758). Средства массовой информации Ненецкого автономного округа неоднократно публиковали сообщения о встречах и гнездовании серых журавлей в бассейне р. Сула (Минеев, 2009).

Tулес Pluvialis squatarola (Linnaeus, 1758). Гнездящийся вид. В период исследований 1986 г. плотность населения тулеса в районе оз. Урдюжское была равна 0.9 особи/км². Откладка яиц происходила с 16 июня. В 1979 г. последних мигрирующих птиц наблюдали 23 сентября (Минеев, 2009). Три гнездовые пары тулесов отмечены 27 июня 2018 г. в кустарничково-мохово-лишайниковой тундре.

Золотистая ржанка Pluvialis apricaria (Gmelin, 1789). Гнездящийся вид. В 1986 г. плотность населения золотистой ржанки в районе оз. Урдюжское в среднем была равна 1.0 особь/км². Проклев птенцов в яйцах происходил 24 июня (Минеев, 2009). В летний период 2018 г. отмечены одиночные особи и пары золотистых ржанок. Плотность населения ржанки в мохово-лишайниково-кустарничковой тундре составила 1.7 особи $/ \mathrm{\kappa м}^{2}$.

Галстучник Charadrius hiaticula Linnaeus, 1758. Возможно, гнездящийся вид. Одиночные особи галстучника отмечены 4 июля 2018 г. на илистых отмелях в северной части оз. Урдюжское.

Фифи Tringa glareola Linnaeus, 1758. Гнездящийся вид. В летний период 1986 г. в районе оз. Урдюжское численность фифи была равна 4.2 особи $/ \mathrm{kм}^{2}$. Однодневные пуховички найдены 3 июля. В выводках зарегистрировано по 2-4, в среднем 3.5 птенца (Минеев, 2009).

В 2018 г. встречены одиночные и пары куликов. Плотность населения фифи в тундровых местообитаниях в районе оз. Урдюжское была равна 2.6, на разнотравных лугах в низовьях p. Сула - 12.0 особей $/$ м $^{2}$. Численность фифи в нижнем течении р. Сула составила 0.4 особи на 10 км лодочного маршрута.

Большой улит Tringa nebularia (Gunnerus, 1767). Одиночные большие улиты зарегистрированы 8 июля 2018 г. в низовьях р. Сула (район 
с. Коткино). Численность куликов составила 0.3 особи на 10 км лодочного маршрута.

Щеголь Tringa erythropus (Pallas, 1764). Щеголи в районе оз. Урдюжское отмечены 10 июля 1986 г., последние мигрирующие особи зарегистрированы 9 сентября 1979 г. (Минеев, 2009).

Перевозчик Actitis hypoleucos (Linnaeus, 1758). Вероятно, гнездится. Летом 2018 г. на р. Урдюжская Виска численность перевозчика была равна 2.9 , в низовьях р. Сула -0.4 особи на 10 км лодочного маршрута.

Мородунка Xenus cinereus (Guldenstadt, 1758). Летом 2018 г. куликов наблюдали в низовьях p. Сула. Встречены одиночные особи, пары и стайки (по 6-10 особей) птиц. Плотность населения куликов на пойменных лугах была равна 8.0 особей $/ \mathrm{k}^{2}$, численность на водотоках -2.8 особи на 10 км лодочного маршрута.

Круглоносый плавунчик Phalaropus lobatus (Linnaeus, 1758). Плотность населения круглоносых плавунчиков в 1986 г. в районе оз. Урдюжское составила 2.6 особи/км² (Минеев, 2009). В период наблюдений 2018 г. кулики не были отмечены.

Tурухтан Phylomachus pugnax (Linnaeus, 1758). Гнездящийся вид. В 1986 г. плотность населения турухтана в районе оз. Урдюжское была равна 2.8, в 2018 г. - 0.3 особи $/$ м $^{2}$ (Минеев, 2009).

Кулик-воробей Calidris minuta (Leisler, 1812). В летний период 1986 г. кулика-воробья наблюдали в районе оз. Урдюжское. Плотность населения птиц была равна 0.1 особи $/ \mathrm{kм}^{2}$ (Минеев, 2009).

Белохвостый песочник Calidris temminckii (Leisler, 1812). Гнездящийся вид. В районе оз. Урдюжское плотность населения белохвостого песочника в мохово-лишайниково-кустарничковой тундре в летний период 1986 г. была равна 2.5 (Минеев, 2009), в 2018 г. -0.6 особи $/$ км $^{2}$.

Чернозобик Calidris alpina (Linnaeus, 1758). Возможно, гнездится. Плотность населения чернозобика в районе оз. Урдюжское в 1986 г. была равна 0.4 особи $/ \mathrm{\kappa м}^{2}$ (Минеев, 2009). В летний период 2018 г. встречены пары и одиночные птицы. В тундровых местообитаниях численность птиц составила 1.0 особи/км².

Гаршнеп Lymnocryptes minimus (Brunnich, 1764). Гаршнеп отмечен 5 июля 2018 г. на приозерных осоковых лугах.

Бекас Gallinago gallinago (Linnaeus, 1758). Гнездящийся вид. Летом 1986 г. численность птиц в районе оз. Урдюжское была равна 0.9 особи/км² (Минеев, 2009). В 2018 г. токующих птиц регулярно регистрировали в кустарничково-мохово-лишайниковой тундре. В этих местообитаниях численность бекаса в среднем была равна 0.7 , на пойменных лугах в низовьях р. Сула 4.0 особи $/ \mathrm{KM}^{2}$.

Дупель Gallinago media (Latham, 1787). Гнездящийся вид. В 2018 г. одиночные птицы отме- чены на осоковых берегах оз. Урдюжское. На пойменных лугах в низовьях р. Сулы численность дупеля составила 6.0 особей $/ \mathrm{kM}^{2}$. Гнездо кулика найдено 9 июля 2018 г. на ивняково-разнотравном лугу в низовьях р. Сула (устье р. Харьяхский Шар). Оно размещалось в траве (высотой 65 см) в 20 м от временного озерка. Гнездо представляло собой ямку, выложенную сухой травой. Диаметр гнезда был равен $16 \mathrm{~cm}$, диаметр лотка - 12.4 см, глубина лотка -4 см. В кладке находилось четыре яйца размером $43.6 \times 31.5$; $45.7 \times 31.6 ; 45.9 \times 31.7 ; 47.4 \times 31.2$ мм.

В 1979, 1982 и 1986 гг. летние перемещения одиночных птиц в районе оз. Урдюжское происходили с 31 июля, они особенно хорошо были выражены в августе. Последних птиц наблюдали 29 сентября (Минеев, 2009).

Вальдшнеп Scolopax rusticola Linnaeus, 1758. Гнездящийся вид. В поймах рек Сула и Сойма ток вальдшнепа регулярно регистрировали в конце июня-начале июля 2018 г. Численность вальдшнепа на пойменных ивняковых разнотравных лугах была равна 2.0 особи/км ${ }^{2}$.

Средний кроншнеп Numenius phaeopus (Linnaeus, 1758). Гнездящийся вид. В 1986 г. плотность населения средних кроншненов в среднем была равна 1.1 особи/км². В 2018 г. численность среднего кроншнепа в кустарничково-моховолишайниковой тундре в среднем составила 1.9 особи $/ \mathrm{kм}^{2}$, в некоторых местообитаниях - 7.7.

Отводящие от гнезд птицы встречены 2 июля 1986 г. Гнездо с одним птенцом найдено 10 июля. Оно было сооружено в торфянистой тундре среди лишайников и представляло собой углубление диаметром 12.5 и глубиной $3 \mathrm{cm,} \mathrm{выложенное}$ лишайниками. В мохово-кочкарниково-травянистой тундре 26 июня найдено разоренное гнездо, около которого находилось одно уцелевшее яйцо (61.9×41.2 мм). Выводок из двух птенцов встречен 26 июля на возвышенной травяно-осоковой тундре. Мигрирующих на север средних кроншнепов (по 1-12 особей) наблюдали с 12 июля 1986 г. (Минеев, 2009).

Малый веретенник Limosa lapponica (Linnaeus, 1758). Гнездящийся вид. В период исследований 2018 г. малые веретенники встречены в одних местообитаниях со средним кроншнепом. Птиц с гнездовым поведением (родители, отводящие от птенцов) неоднократно регистрировали в кустарничково-мохово-лишайниковой тундре.

В районе оз. Урдюжское численность веретенника в 1986 г. в среднем была равна 0.6, в 2018 г. 1.2 особи $/ \mathrm{\kappa м}^{2} .19$ июня 1986 г. найдено гнездо (Минеев, 2009). Оно представляло собой углубление $(10 \mathrm{~cm})$ в багульниково-лишайниковой кочке (высотой 30 см) среди сырого участка болота. Диаметр гнезда 15 см, глубина лотка - 1.5 см. Гнездо содержало пять яиц: $49.1 \times 37.0 ; 47.1 \times 39.4$; $48.7 \times 37.7 ; 49.0 \times 35.9 ; 51.3 \times 36.3 \mathrm{мм}$. 
Средний поморник Stercoraius pomarinus (Temminck, 1815). В районе оз. Урдюжское миграция средних поморников происходила с 29 сентября 1979 г. (Минеев, 2009).

Короткохвостый поморник Stercorarius parasiticus (Linnaeus, 1758). Короткохвостый поморник в 2018 г. отмечен на пойменных лугах в низовьях р. Сула. Плотность населения вида в этих местообитаниях в среднем составила 1.1 особи/км ${ }^{2}$.

В 1986 г. в районе оз. Урдюжское летняя миграция поморников происходила с 18 июля по 5 августа. Птицы поодиночке и группами по 3-9 особей летели на восток (около 55 \%), юго-восток (свыше $16 \%$ ), юго-запад (около $11 \%$ ), на северо-восток (более $9 \%$ ) и запад (свыше $8 \%$ ). Размножающиеся короткохвостые поморники из мест размножения отлетали в первой декаде сентября (Минеев, 2009).

Длиннохвостый поморник Stercorarius longicaudus Vieillot, 1819. Гнездящийся вид. Одиночные птицы, пары и стайки (по 3-5 особей) мигрирующих на восток длиннохвостых поморников зарегистрированы 7-8 июля 2018 г. в районе оз. Урдюжское и низовьях р. Сула. Плотность населения длиннохвостого поморника в районе исследований была равна 1.8 особи $/ \mathrm{Kм}^{2}$. В низовьях р. Сула численность вида составила 0.5 особи на 10 км учетного маршрута.

В 1986 г. в районе оз. Урдюжское плотность населения птиц была равна 1.3 особи /км² (Минеев, 2009). Мигрирующие на восток длиннохвостые поморники (по 1-7 особей) зарегистрированы с 9 июня по 1 августа 1986 г. Последние поморники отмечены в конце сентября (1979 г.).

Озерная чайка Larus ridibundus Linnaeus, 1766. Одиночная озерная чайка отмечена 8 июля 2018 г. в низовьях р. Сула.

Серебристая чайка Larus argentatus Pontoppidan, 1763. Гнездящийся вид. В районе исследований в 2018 г. встречены одиночные особи, пары и стайки (7-8 особей) чаек. Плотность населения птиц в тундровых местообитаниях была равна 0.4 особи $/ \mathrm{\kappa M}^{2}$.

Кочующие неполовозрелые (2-4 года) и не размножающиеся серебристые чайки отмечены в районе оз. Урдюжское 14 июля 1986 г. В это время мигрировали одиночные птицы и небольшие стайки (до 6 особей) на запад и юго-запад. В послегнездовое время плотность населения чаек в среднем была равна 0.7 особи $/$ м $^{2}$ (Минеев, 2009).

Бургомистр Larus hyperboreus Gunnerus, 1767. Одиночные особи и группы (до 3 особей) бургомистров встречались в период весенних и летних кочевок (19-30 июня 1986 г.). Взрослые и неполовозрелые (во втором и третьем нарядах) птицы отметены в редколесьях района оз. Урдюжское (Минеев, 2009).
Сизая чайка Larus canus Linnaeus, 1758. Гнездящийся вид. В районе оз. Урдюжское неразмножающиеся сизые чайки (стаи до 28 особей) отмечены 5 июля 1986 г. Осенний отлет птиц поодиночке, парами, семейными группами и стаями (по 5-25 особей) на юго-восток и запад в этом районе происходил 11 сентября-4 октября 1979 и 1982 гг. Наиболее поздние мигранты (по 1-5 особей) были представлены почти исключительно молодыми птицами. По материалам авиаучетов в сентябре 1976 г. плотность населения чаек в районе оз. Урдюжское была равна 0.03 особи/ км ${ }^{2}$ (Минеев, 2009).

При исследованиях 2018 г. отмечены одиночные особи, пары и стайки (4-22 особи) сизых чаек. Плотность населения птиц в кустарничково-мохово-лишайниковой тундре (район оз. Урдюжское) была равна 1.5, на пойменных ивняковых разнотравных лугах в низовьях р. Сула -4.4 особи/км² ${ }^{2}$ В низовьях р. Сула вдоль русла реки численность сизой чайки составила 3.7 особи на 10 км учетного маршрута.

Полярная крачка Sterna paradisaea Pontoppidan, 1763. Гнездящийся вид. Плотность населения полярных крачек в районе оз. Урдюжское в летний период 1986 г. в среднем была равна 1.8 особи $/ \mathrm{k}^{2}$. Летняя миграция крачек поодиночке, парами и стаями (до 26 особей) зарегистрирована 24 июня 1986 г. Отлет выражен в июле, птицы по 2-40 особей мигрировали на север (Минеев, 2009).

В летний период 2018 г. одиночные особи, пары и стайки (по 6-25 особей) полярных крачек отмечены в районе оз. Урдюжское, одиночные и стайки птиц (до 10 особей) - в низовьях р. Сулы. На пешеходных маршрутах в районе оз. Урдюжское плотность населения полярной крачки была равна 5.2 особи $/ \mathrm{kм}^{2}$.

Желна Dryocopus martius (Linnaeus, 1758). C.A. Петрусенко (личное сообщение) в 80-е гг. $\mathrm{XX}$ в. регулярно встречал желну в лесах по берегам р. Сула.

Пестрый дятел Dendrocopus major (Linnaeus, 1758). Гнездящийся вид. В период исследований 2018 г. плотность населения пестрого дятла в лесных массивах составила 1.3 особи $/ \mathrm{\kappa м}^{2}$. В елово-березовом лесу (северное побережье оз. Урдюжское) 6 июля 2018 г. найдено жилое дупло. Оно было сооружено на высоте 4 м в старой сухой березе (высотой 5-6 м). Нежилое дупло обнаружено рядом, также в березе.

Береговая ласточка Riparia riparia (Linnaeus, 1758). Вероятно, гнездится. В районе оз. Урдюжское первые береговушки отмечены 22 июня 1986 г. (Минеев, 2009). Отдельные береговые ласточки в 2018 г. встречены в северной части оз. Урдюжское. В низовьях р. Сулы тисленность ласточек-береговушек была равна 3.7 особи на 10 км учетного маршрута. 
Деревенская ласточка Hirundo rustica Linnaeus, 1758. Одиночную ласточку наблюдали 21 июня 1986 г. около домов на оз. Урдюжское (Минеев, 2009). Стайки (из 2-3 особей) деревенских ласточек, кормящихся в районе домов (исток p. Урдюжская Виска), отмечены 22 июня 2018 г.

Воронок Delichon urbica (Linnaeus, 1758). Стаю (около 50 особей) городских ласточек зарегистрировали 8 июля 2018 г. в с. Коткино.

Луговой конек Anthus pratensis (Linnaeus, 1758). Луговой конек встречен среди прибрежных кустарниковых зарослей ольхи и ивы в районе оз. Урдюжское. Брачные токовые игры отдельных самцов наблюдали 23 июня 1986 г. (Минеев, 2009).

Краснозобый конек Anthus cervinus (Pallas, 1811). Гнездящийся вид. Плотность населения птиц в районе оз. Урдюжғское в 1986 г. была равна 1.5 особи $/$ м $^{2}$. Полные кладки (из 5-6 яиц) находили 23-29 июня. В 2018 г. краснозобый конек встречался в кустарничково-мохово-лишайниковой тундре и массивах елово-березового леса. Численность конька в среднем составила 8.4 особи $/ \mathrm{Kм}^{2}$. Гнездо конька найдено 22 июня 2018 г. в кочкарнике кустарничково-мохово-лишайниковой тундры. В районе оз. Урдюжское последних отлетающих краснозобых коньков наблюдали 25 сентября 1979 г. и 1982 г. (Минеев, 2009).

Желтая трясогузка Motacilla flava (Linnaeus, 1758). Гнездящийся вид. В районе оз. Урюджское желтая трясогузка была обычна в березовоеловых редколесьях с обширными участками ивняково-кочкарниковых и ерниковых тундр. Гнезда, найденные 1 и 2 июля 1986 г., были размещены на кочках под прикрытием кустарничков багульника и черники, багульника и водяники. Они $(\mathrm{n}=2)$ имели диаметр 8 и $9 \mathrm{~cm}$, лотка6.0 и $6.5 \mathrm{~cm}$, глубина лотка -3.5 см. Гнезда были построены из травы, в одном гнезде подстилкой лотка служили перья белой куропатки. В кладках находились яйца размером 17.9-20.9×14.015.4 мм, в среднем $(\mathrm{n}=11)-18.9 \times 14.6$ мм (Минеев, 2009).

Летом 2018 г. пары желтой трясогузки встречены в районе оз. Урдюжское в кустарничковомохово-лишайниковой тундре и массивах еловоберезового леса. Плотность населения птиц была равна 2.9 особи $/ \mathrm{\kappa м}^{2}$.

Желтоголовая трясогузка Motacilla citreola Pallas, 1776. Гнездящийся вид. Птиц, носящих строительный материал для гнезд, наблюдали с 13 июня. В 1986 г. плотность населения трясогузки в среднем была равна 3.4 особи $/ \mathrm{\kappa м}^{2}$ (Минеев, 2009). В летний период 2018 г. гнездовые пары желтоголовой трясогузки отмечены в мохово-лишайниково-кустарничковой тундре (район оз. Урдюжское), где ее тисленность составила 5.5 особи $/ \mathrm{\kappa м}^{2}$. На пойменных ивняково-разнотравных лугах в низовьях р. Сула численность трясогузки была равна 10 особей $/ \mathrm{\kappa м}^{2}$.
Белая трясогузка Motacilla alba Linnaeus, 1758. Гнездящийся вид. В тундровых местообитаниях плотность населения белой трясогузки была равна 2.9 особи $/ \mathrm{kм}^{2}$, в бассейне р. Урдюжская Виска - 0.9 особи на 10 км учетного маршрута. Гнездо трясогузки найдено 27 июня 2018 г. под крышей дома (оз. Урдюжское). В гнезде находились трехдневные птенцы.

Одиночных белых трясогузок наблюдали до 1 октября 1979 г. (Минеев, 2009).

Серый сорокопут Lanius excubitor Linnaeus, 1758. Одиночные серые сорокопуты зарегистрированы летом 1986 г. (Минеев, 2009) и 3 июля 2018 г. в елово-березовых редколесьях района оз. Урдюжское.

Кукша Perisoreus infaustus (Linnaeus, 1758). Одна особь кукши встречена 14 июля 1986 г. в березовом колке на р. Средний Гусинец, впадающей в оз. Урдюжское (Минеев, 2009).

Серая ворона Corvus corone (Linnaeus, 1758). Гнездящийся вид. В период рыбодобычи (1979, 1982,1986 гг.) численность серой вороны в районе оз. Урдюжское в послегнездовое время варьировала от 0.8 до 16.0 особей $/ \mathrm{\kappa м}^{2}$. В период исследований 2018 г. в районе оз. Урдюжское серая ворона была немногочисленна $\left(0.2\right.$ особи $\left./ \mathrm{kм}^{2}\right)$. На пойменных лугах в низовьях р. Сула численность вороны была равна 3.3 особи $/$ км$^{2}$, а по данным лодочных маршрутов в низовьях реки этот показатель составил 0.2 особи на 10 км учетного маршрута.

В районе оз. Урдюжское серые вороны (пары, молодые особи с родителями и стаи по 10-17 птиц) 13-24 сентября 1979 г. мигрировали на восток, запад и юг. Последнего мигранта (молодая птица) в этом районе наблюдали 14 октября (Минеев, 2009).

Ворон Corvus corax Linnaeus, 1758. Гнездящийся вид. В летний период 2018 г. пары ворона регулярно регистрировали в районе оз. Урдюжское. Выводок с тремя летными птенцами встречен на Урдюжской Виске 21 июня. Численность птиц в тундровых местообитаниях составила 0.5 особи $/$ км $^{2}$, в низовьях р. Сула -0.1 особи на 10 км учетного маршрута.

В районе оз. Урдюжское кочевки одиночных особей, пар и семейных группировок ворона в северо-западном и южном направлениях отмечены с 15 сентября по 14 октября 1979 г. (Минеев, 2009).

Свиристель Bombycilla garrullus (Linnaeus, 1758). Пары и одиночных свиристелей наблюдали 17-19 июня 1986 г. в елово-березовых и березовых колках района оз. Урдюжское (Минеев, 2009).

Камышевка-барсучок Acrocephalus schoenobaenus (Linnaeus, 1758). Гнездящийся вид. Птицы встречены в ивняках, приуроченных к заболоченным понижениям, озерам, рекам и протокам. Плотность населения камышевки-барсучка 
в районе оз. Урдюжское летом 2018 г. была равна 4.0 особи $/ \mathrm{KM}^{2}$.

Пеночка-весничка Phylloscopus trochilus (Linnaeus, 1758). Гнездящийся вид. В 1979, 1982, 1986 гг. птицы были обычны (в среднем 8.4 особи $/ \mathrm{\kappa м}^{2}$ ) в ивняках и елово-березовых лесах района оз. Урдюжское. В 2018 г. плотность населения веснички в районе оз. Урдюжское была равна 26.5 особи $/ \mathrm{\kappa м}^{2}$, на пойменных ивняково-разнотравных лугах в низовьях р. Сула - 30.0 особей $/ \mathrm{\kappa м}^{2}$.

Гнезда с полными кладками найдены с 17 июня по 14 июля 1986 г. Они содержали по 5-7 яиц, в среднем $(\mathrm{n}=8) 5.9$ яиц размером $14.7-16.8 \times$ 11.3-12.4 мм, в среднем $(\mathrm{n}=14)-15.7 \times 11.8$ мм. В некоторых гнездах 14 июля птенцы уже вылупились из яиц, в других - были птенцы и проклюнувшиеся яйца. Последние веснички, отлетающие из мест гнездования, отмечены 25 сентября 1979 г. (Минеев, 2009).

Пеночка-таловка Phylloscopus borealis (Blasius, 1858). Гнездящийся вид. Основные местообитания таловки - березовые и березово-еловые колки, прирусловые елово-березовые редколесья. Плотность населения птиц в районе оз. Урдюжское в летний период 1986 г. в среднем была равна 4.3 (Минеев, 2009), в 2018 г. - 13.8 особи/ $\kappa^{2}$, на пойменных разнотравно-ивняковых лугах в низовьях р. Сулы - 50.0 особей $/ \mathrm{\kappa м}^{2}$.

Обыкновенная каменка Oenanthe oenanthe (Linnaeus, 1758). Гнездящийся вид. Пары обыкновенных каменок отмечены в мохово-лишайниково-кустарничковой тундре района оз. Урдюжское летом 2018 г. Плотность населения птиц составила 1.3 особи $/ \mathrm{KM}^{2}$.

Варакушка Luscinia svecica (Linnaeus, 1758). Гнездящийся вид. В районе оз. Урдюжское последних одиночных варакушек наблюдали 13 октября 1979 г. Высокая плотность населения варакушки (7.4 особи/км²) отмечена летом 1986 г. Гнездо с только что появившимися двумя птенцами и двумя яйцами найдено 15 июля. При осмотре этого гнезда 25 июля у птенцов была оперена спина, на крыльях появились кисточки перьев, а 27 июля птенцы были почти полностью оперены. В двух других гнездах 27 июля птенцы уже покинули гнезда (Минеев, 2009). В летний период 2018 г. численность варакушки в кустарничково-мохово-лишайниковой тундре была равна 3.1 особи $/ \mathrm{Kм}^{2}$, в островных лесах -15.0 , в прибрежных местообитаниях - 12.4 и в пойме Урдюжской Виски - 5.0 особей на 10 км учетного маршрута.

Рябинник Turdus pilaris Linnaeus, 1758. Heбольшие стайки дроздов (район оз. Урдюжское), мигрирующих в западном направлении, наблюдали в последних числах сентября 1979 г. (Минеев, 2009). В 2018 г. рябинник не отмечен в районе оз. Урдюжское. На пойменных лугах низовий р. Сула численность дрозда была равна 8.0 особей $/ \mathrm{KM}^{2}$.
Белобровик Turdus iliacus Linnaeus, 1766. Гнездящийся вид. В тундровых местообитаниях оз. Урдюжское в 2018 г. плотность населения белобровика была равна 2.1 особи/км². Гнездование зарегистрировано в березняке.

В 1979 г. последние белобровики окончательно отлетели из мест гнездования 23 сентября (Минеев, 2009).

Певчий дрозд Turdus philomelos C.I. Brehm, 1831. Токовые песни певчего дрозда отмечены 4 июля 2018 г. на расширении протоки в северной части оз. Урдюжское в островном елово-березовом лесу.

Сероголовая гаичка Parus cinctus Boddaert, 1783. Одиночную сероголовую гаичку наблюдали 12 октября 1982 г. в березняках по берегам оз. Урдюжское (Минеев, 2009).

Юрок Fringilla montifringilla (Linnaeus, 1758). Гнездящийся вид. Юрок встречен в мохово-лишайниковой тундре, елово-березовых лесах и редколесьях. Летом 1986 г. плотность населения юрка в районе оз. Урдюжское была равна 9.8 особи $/$ м $^{2}$ (Минеев, 2009), в 2018 г. - 9.1, а на пойменных лугах в низовьях р. Сула - 70.0 особей $/ м^{2}$. На р. Урдюжская Виска численность птиц была равна 0.6 , на р. Сула -1.0 особь на 10 км учетного маршрута.

Обыкновенная чечетка Acantis flammea (Linnaeus, 1758). Гнездящийся вид. Плотность населения чечеток в районе оз. Урдюжское (1979, 1982,1986 гг.) в среднем была равна 10.6 особи/ км² (Минеев, 2009). Найденное 23 июня 1986 г. гнездо диаметром 8.5 см, лоток -4.5 см и глубиной 3.5 см было размещено в развилке невысокой березы на высоте $65 \mathrm{~cm}$ от земли. Оно было сооружено из травы. Кладка содержала пять яиц размером $17.2-16.1 \times 13.0-13.6$, в среднем $16.7 \times$ 13.2 мм. Миграция молодых чечеток (самостоятельные стаи и совместно с половозрелыми птицами) в районе оз. Урдюжское продолжалась до 14 октября.

В 2018 г. плотность населения обыкновенной чечетки в тундровых местообитаниях оз. Урдюжское составила 1.0 особь $/ \mathrm{KM}^{2}$, на р. Урдюжская Виска численность птиц была равна 0.9 особи на 10 км учетного маршрута.

Обыкновенный клест Loxia curvirostra Linnaeus, 1758. Одиночные обыкновенные клесты встречены во второй половине июня 1986 г. в елово-березовых редколесьях на берегу р. Средний Гусинец, впадающей в оз. Урдюжское (Минеев, 2009).

Белокрылый клест Loxia leucoptera Gmelin, 1789. Белокрылых клестов наблюдали летом 2018 г. в елово-березовых лесах северной части оз. Урдюжское. Численность птиц в этих местообитаниях в среднем составила 3.3 особи/км ${ }^{2}$.

Тростниковая овсянка Emberiza schoeniclus (Linnaeus, 1758). Гнездящийся вид, отмеченный ранее (Минеев, 2009). В районе оз. Урдюжское в 
2018 г. регулярно регистрировали одиночных особей и пары тростниковых овсянок.

Овсянка-крошка Emberiza pusilla Pallas, 1776. Гнездящийся вид. В 1986 г. плотность населения овсянок-крошек в районе оз. Урдюжское была равна 5.6 особи $/$ м $^{2}$. Полные кладки найдены с 23 июня по 1 июля, они содержали по $1-4$, в среднем $(n=3) 3.0$ яйца, размером 17.1-16.9× 13.3-13.9 мм, в среднем $(\mathrm{n}=4) 16.9 \times 13.4$ мм. Появление птенцов отмечено 27 июня (Минеев, 2009).

В 2018 г. плотность населения овсянки-крошки в тундровых местообитаниях была равна 3.5 особи $/ \mathrm{KM}^{2}$, в елово-березовом лесу - 13.3 особи/ $\kappa^{2}$. На разнотравно-ивовых лугах в низовьях р. Сула численность овсянки составила 70 особей $/$ м $^{2}$. Гнезда найдены 23 и 30 июня 2018 г. среди кустарничково-мохово-лишайниковой тундры. Они были размещены под кочками и сооружены из сухой травы. Кладки содержали по шесть яиц.

Подорожник Calcarius lapponicus (Linnaeus, 1758). Гнездящийся вид. Летом 1986 г. плотность населения подорожника в районе оз. Урдюжское была равна 6.6 , в 2018 г. - 7.1 особи $/$ км² $^{2}$ Последние о'летающие из мест размножения подорожники отмечены 29 сентября 1979 г. (Минеев, 2009).

Пуночка Plectrophenax nivalis (Linnaeus, 1758). Миграция пуночек (стайками по 4-8 особей) в районе оз. Урдюжское отмечена 13-20 сентября 1979 г., более крупные стаи (до 30 особей) мигрировали на запад и юг 3-15 октября 1982 г. (Минеев, 2009).

\section{Обсуждение результатов}

В ходе исследований 1979, 1982, 1986 и 2018 гг. в районе оз. Урдюжское, бассейнах рек Сойма и Сула зарегистрировано 98 видов птиц, принадлежащих к восьми отрядам: гагарообразные (2 вида), пластинчатоклювые (19), соколообразные (13), курообразные (4), журавлеобразные (1), ржанкообразные (27), дятлообразные (2), воробьинообразные (30). Из общего числа выявленных видов гнездятся 64 (65.3\%), предположительно гнездятся 10 (10.2\%), встречено на миграциях шесть (6.1\%), залетными являются пять (5.1\%), характер пребывания не выяснен для 14 (14.3\%) видов птиц.

В 1979, 1982, 1986 гг. в районе оз. Урдюжское зарегистрировано пребывание 73, в 2018 г. 60 видов птиц. Во все периоды на всех участках наблюдений зарегистрировано 48 видов птиц. В бассейнах рек Сула и Сойма в 2018 г. отмечено 28 видов, но не подтверждены литературные данные о пребывании большого крохаля, тетерева, глухаря, рябтика и эжелны.

В летний период 2018 г. в районе оз. Урдюжское численность птиц в елово-березовом лесу была равна 186.7 (9 видов птиц), а в кустарнич- ково-мохово-лишайниковой тундре - 92.4 (38 видов птиц) особи/км². Наиболее многочисленными в кустарничково-мохово-лишайниковой тундре были следующие виды: лебедь-кликун (2.6 особи $/$ м $\left.^{2}\right)$, золотистая ржанка (2.1), фифи (2.6), лапландский подорожник (7.1). В лесных местообитаниях - юрок (26.7 особи/ $\left.\mathrm{kм}^{2}\right)$, таловка (60) и весничка (60 особей/ км²).

Плотность населения птиц на пойменных лугах в низовьях р. Сула составила 295.5 особи/ км$^{2}$ (18 видов птиц). Наиболее многочисленными были следующие виды: широконоска (6.7 особи/ $\mathrm{Kм}^{2}$ ), фифи (12.0), мородунка (8.0), весничка (30), таловка (50), юрок (70) и овсянка крошка (70 особей $\left./ \mathrm{\kappa M}^{2}\right)$.

В бассейне Урдюжской Виски численность птиц была равна 14.1 (13 видов), а в низовьях Сулы - 19.8 (16) особи на 10 км учетного маршрута. На Урдюжской Виске многочисленными были перевозчик (2.9), орлан-белохвост $(0.9)$, белая трясогузка (0.9) и овсянка-крошка (0.9), а в низовьях Сулы мородунка (2.8), сизая чайка (3.7), ласточка-береговушка (3.7) и юрок (1 особь/км²).

В характере населения птиц исследованного района (оз. Урдюжское) за прошедший период (более 30 лет) выявлены заме'ные изменения, связанные с прекращением активной деятельности людей (промысловая ловля рыбы) в летний период: значительное снижение численности серой вороны, увеличение численности гнездящихся орланов-белохвостов, район стал местом крупной концентрации лебедей-кликунов на линьке. Отмечено сокращение численности гуменника, морянки, турухтана, что, вероятно, обусловлено циклическими процессами динамики гнездования первого вида и общим снижением численности последних в целом по региону (Ануфриев, 2019). Отсутствие находок гнездования кречета в летний период 2018 г., вероятно, связано с низкой численностью белой куропатки в Восточно-европейских тундрах на протяжении нескольких последних лет (Circumpolar ..., 2019) - основного объекта питания вида.

Исследования, проведенные в районе оз. Урдюжское, показали, что этот район является важным местом обитания и линьки кликуна, ржанкообразных птиц, орлана-белохвоста и может быть выделен как территория, подпадающая под действие Рамсарской конвенции.

\section{ЛИТЕРАТУРА}

Ануфриев, В. В. Морянка Clangula hyemalis (Linnaeus, 1758) // Красная книга Ненецкого автономного округа. 2-е издание / отв. ред. Н. В. Матвеева ; науч. ред. И. А. Лавриненко, О. В. Лавриненко, В. В. Морозов. - Нарьян-Мар, 2019. - с. 411.

Горбацкий, Г. В. Физико-географическое районирование Арктики. Ч. 1. / Г. В. Горбацкий. - Ленинград, 1967. - 136 с.

Дедов, А. А. Растительность Малоземельской и Тиманской тундр / А. А. Дедов. - Сыктывкар, 2006. $159 \mathrm{c}$. 
Минеев, О. Ю. Водоплавающие птицы Малоземельской тундры и дельты р. Печоры / О. Ю. Минеев. Екатеринбург, 2005. - 161 с.

Минеев, О. Ю. Биология размножения и численность морянки в восточно-европейских тундрах России / О. Ю. Минеев, Ю. Н. Минеев // Гусеобразные северной Евразии: изучение, сохранение и рациональное использование : международная конференция. Салехард, 2015. - С. 54-55.

Минеев, Ю. Н. Гусеобразные птицы восточноевропейских тундр / Ю. Н. Минеев. - Екатеринбург, 2003. 225 c.

Минеев, Ю. Н. Лебеди европейского северо-востока России / Ю. Н. Минеев, О. Ю. Минеев. - Сыктывкар, 2014. - 128 c.

Минеев, Ю. Н. Птицы Малоземельской тундры и дельты Печоры / Ю. Н. Минеев, О. Ю. Минеев. - СанктПетербург : Наука, 2009. - 263 с.

Минеев, Ю. Н. Редкие хищные птицы в тундрах европейского северо-востока СССР / Ю. Н. Минеев //
Сезонная ритмика редких и исчезающих видов растений и животных. - Москва, 1980. - С. 133-134.

Семенов, Б. Т. Промысловые птицы Тиманской тундры / Б. Т. Семенов // Известия государственного географического общества. - 1939. - Т. 71, вып. 4. C. 569-579.

Степанян, Л. С. Конспект орнитологической фауны России и сопредельных территорий / Л. С. Степанян. - Москва, 2003. - 727 с.

Circumpolar status of Arctic ptarmigan: Population dynamics and trends / Eva Fuglei, Henden John-Andre, Chris T. Callahan, Olivier Gilg, Jannik Hansen, Rolf A. Ims, Arkady P. Isaev, Johannes Lang, Carol L. McIntyre, Richard A. Merizon, Oleg Y. Mineev, Yuri N. Mineev, Dave Mossop, Olafur K. Nielsen, Erlend B. Nilsen, Ashild Onvik Pedersen, Niels Martin Schmidt, Benoit Sittler, Maria Hornell Willebrand, Kathy Martin // Ambio. - DOI: 10.1007/s13280-019-01191-0. 2019. P. 1-13.

\title{
BIRDS OF THE URDYUZHSKOE LAKE AND THE LOWER COURSE OF THE SULA RIVER (MALOZEMELSKAYA TUNDRA)
}

\author{
O.Yu. Mineev, Yu.N. Mineev, S.K. Kochanov \\ Institute of Biology of Komi Science Center of the Ural Branch of the Russian Academy of Sciences, Syktyvkar
}

Summary. The article presents the results of studies in 1979, 1982, 1986 and 2018 on the distribution and population of birds of the Urdyuzhskoye Lake of and the lower course of the Sula River. We registered 98 bird species from 8 orders: divers (2 species), anseriformes (19), falconiformes (13), grouses (4), cranes (1), charadriiformes (27), woodpeckers (2), and passerine (30). 64 species are nesting, 10 - presumably nesting, 6 species were encountered during migrations, 5 species are vagrant, and 14 bird species are of not clear status. For more than 30 years (from 1986 to 2018), we revealed noticeable changes in the bird populations in Urdjuzhskoye Lake area. These changes are probably associated with the cessation of economic activities of people (commercial fishing) in the summer period. As a result, the population of hooded crow has significantly decreased, the area has become a place of large concentration of whooper swans during molting, and the nesting density of white-tailed eagles has increased. The reason of low number of the bean goose is unclear. So, the research carried out near the Urdjuzhskoe Lake, showed that this area is a key habitat and molt of whooper swan, charadriiformes, white-tailed eagle and falls under the Ramsar Convention.

Key words: Malozemelskaya tundra, Urdyuzhskoe Lake, basin of the Sula river, distribution, birds population 